\title{
Tundra Bean Geese Anser fabalis rossicus in central and southern Sweden autumn 2009-spring 2012
}

\author{
Thomas Heinicke ${ }^{1} \&$ Adriaan de Jong ${ }^{2}$ \\ ${ }^{1}$ International Bean Goose project, Gingster Str. 18, D-18573 Samtens, Germany \\ ${ }^{2}$ Dept. of Wildlife, Fish, and Environmental Studies, Swedish University of Agricultural Sciences, SE-901 83 Umeå, Sweden; \\ e-mail: adriaan.de.jong@slu.se
}

\begin{abstract}
Daytime counts at 35 staging/wintering sites in 2009-2012 revealed that total numbers of Tundra Bean Geese Anser fabalis rossicus present in central and southern Sweden often reached 5000-10000. In mild winters, many of these birds stay in Sweden, mainly in the Hammarsjön area, in NE Scania. These findings show that the current population size of the Taiga Bean Goose A. f. fabalis is seriously over-estimated.
\end{abstract}

Key words: Tundra Bean Goose, Taiga Bean Goose, population estimate, flyway, conservation

\section{INTRODUCTION}

In Europe, the Tundra Bean Goose Anser fabalis rossicus is far more numerous than the Taiga Bean Goose Anser fabalis fabalis (Fox et al. 2010), and in many staging and wintering areas, only small numbers of Taiga Bean Geese are present among a multitude of Tundra Bean Geese. In Sweden, the situation is reversed, because here the vast majority of Bean Geese are Taiga Bean Geese (Nilsson \& Månsson 2012). During goose counts under suboptimal conditions for the separation of these two subspecies (e.g. roostflight counts or under poor observational conditions), all Bean Geese are commonly assumed to belong to the presumably commonest subspecies, in Sweden the Taiga Bean Goose. This reinforces the general conception among birdwatchers that the rare subspecies is really rare, and that there is no real reason to separate and report the different subspecies. In the Swedish Report System For Birds ("Svalan") only $0.3 \%$ of the 1.5 million Bean Geese reported up to July 2009 were classified at the subspecies level, despite the technical option to do so (de Jong 2010b). The Swedish goose counts do not distinguish between fabalis and rossicus Bean Geese, but the results are reported as Taiga Bean Geese to Wetland International (Nilsson 2000, KampePersson 2011).

Given the limited population size and the recent decline of the Taiga Bean Goose population (Fox et al. 2010), uncertainty about the subspecies structure in Sweden, the dominant country for Taiga Bean Geese, is a serious problem for conservation and management. In order to clarify the numbers of staging and wintering Tundra Bean Geese in Sweden, and thus to improve the Taiga Bean Goose population estimates, we conducted subspecies level day-time counts of Bean Geese at the major staging and wintering sites in southern and central Sweden. An additional aim was to locate the wintering areas of the recently discovered Northwest European population of the Tundra Bean Goose (Aarvak \& Øien 2009, Heinicke 2010). Birds of this population had been neck-banded during wing-moult in northern Norway (de Jong 2010a) and during spring migration in northern Sweden (Heinicke 2010, Nilsson et al. 2010), but very few had been reported by Swedish birdwatchers.

\section{METHODS}

Sites were selected on the basis of information from the international goose counts in Sweden (http://www. zoo.ekol.lu.se/waterfowl/index_e.htm), the Swedish Report System For Birds (http://www.artportalen.se/ birds/default.asp) and local birdwatchers (Appendix 1). Additional sites were found because they appeared "promising" on maps and satellite/aerial images. All counts were made by Thomas Heinicke between September 2009 and April 2012 (Table 1), and each counting trip was planned to fit the current information about the distribution of the geese and time-constrained logistics (Appendix 1). The timing of the trips in September, October, November and January aimed to coincide with the international goose count dates as far as was possible.

The surveys (counts and neck-band searches) were carried out during day-time at feeding and resting areas. These farmland areas were usually within 10 $\mathrm{km}$ from the night-roost (c.f. Nilsson \& Persson 1984). Unlike roost-flight counts, this method enables reliable distinction of Taiga and Tundra Bean Geese, because the geese can be closely examined by telescope over 
Table 1. Total counts of Tundra Bean Geese during 20092012 in southern and central Sweden (Appendix 1 for site coverage).

\begin{tabular}{lcl}
\hline Period & $\begin{array}{c}\text { Number } \\
\text { of birds }\end{array}$ & Comment \\
\hline Sept 2009 & 1620 & \\
Oct 2009 & 9195 & \\
Jan 2010 & 1208 & \\
April 2010 & 1145 & \\
Sept 2010 & 1626 & \\
Oct 2010 & 5763 & \\
Nov 2010 & 5433 & \\
Jan 2011 & 61 & Severe winter \\
March 2011 & 2722 & \\
April 2011 & 2515 & \\
Sept 2011 & 104 & Geese arrived later \\
Oct 2011 & 7793 & \\
Nov 2011 & 4455 & \\
Jan 2012 & 5373 & Mild winter \\
March 2012 & 3745 & \\
April 2012 & 2963 & \\
\hline
\end{tabular}

substantial periods of time. During the course of our study, gradually more feeding areas were detected around most roosts, e.g. additional areas were found each year west and southwest of the Hammarsjön roost. New areas were found by following geese leaving the night-roost or simply by scanning potential farmland areas within reasonable distances from the roost. This variable, but gradually improving, spatial coverage means that the results should be seen as minimum numbers that are not fully comparable between counting events.

\section{RESULTS AND DISCUSSION}

Single birds or small flocks of Tundra Bean Geese were detected at most of the surveyed sites, but $>100$ rossicus were only found at the following sites (Figure 1, Table 2): Östen, Tåkern, Kvismaren and Ledskärsviken in central Sweden, and Hammarsjön, Trolle-Ljungby, Mörlunda/Hultsfred and Mörbylanga/Öland in southern Sweden. Tundra Bean Goose numbers $>1000$

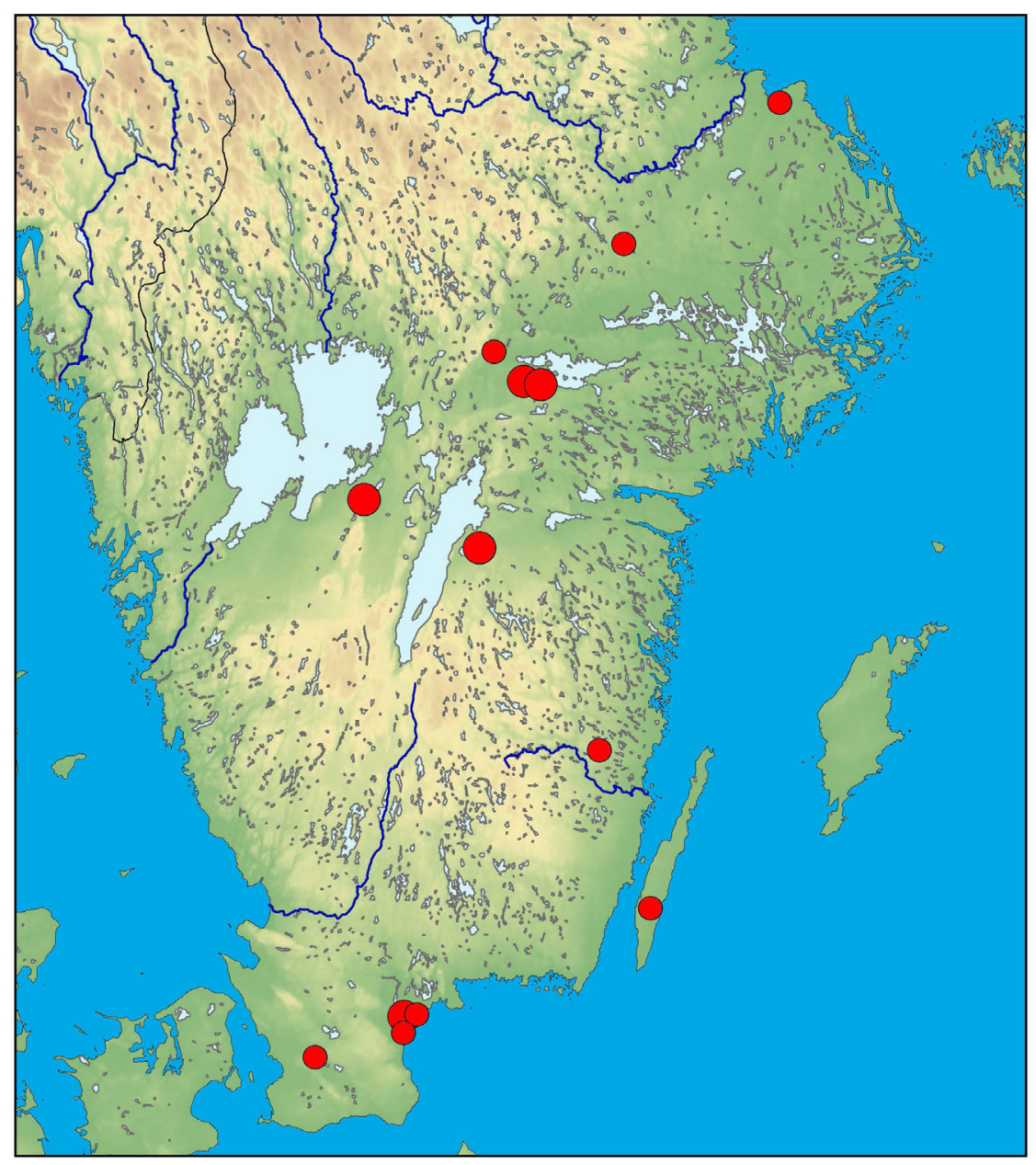

Figure 1. Goose staging and wintering sites in central and southern Sweden where substantial numbers of Tundra Bean Geese were found. Large dots: $>1000$ individuals, small dots: $>100$ individuals. Sites with daily totals $>1000$ were Kvismaren, Östen, Tåkern and Hammarsjön. Segersjön, a sub-site of Kvismaren, also reached the >1000 level. 
Table 2. Maximum numbers of Tundra Bean Geese observed during this study over counting months and the four major staging/wintering sites (see Appendix 1 for schedule of counts).

\begin{tabular}{lrrrrrr}
\hline Site & Sept & Oct & Nov & Jan & March & April \\
\hline Tåkern & 1320 & 2340 & 185 & - & 500 & 612 \\
Kvismaren & 277 & 4090 & 0 & - & 756 & 274 \\
Östen & 681 & 2732 & 6 & - & 2244 & 1875 \\
Hammarsjön & - & 14 & 5042 & 4988 & 2712 & - \\
\hline
\end{tabular}

were counted at sites Kvismaren, Östen, Tåkern and Hammarsjön (Figure 1).

The highest overall number per count session was 9,195 individuals (October 2009, Table 1), but another four $(25 \%)$ of the counts produced totals of $>5000$ geese. The highest numbers were recorded during the October counts, but also in January $>5000$ geese were present under mild winter conditions $(2011 / 12$, Table $1)$.

During autumn migration (Sept-Oct), most Tundra Bean Geese concentrated around Lakes Östen, Tåkern and Kvismaren (central Sweden), where numbers regularly exceeded 1000 birds per site (Table 2). During the winter months (Nov-March), Lake Hammarsjön near Kristianstad, NE Skåne was the most important site; with over 5000 birds present (November 2010). In mid-April, concentrations of several hundred rossicus were found at the following places in central Sweden: Östen, Tåkern and Ledskärsviken.

The presence of substantial numbers of Tundra Bean Geese has been questioned by Swedish birdwatchers, including goose counters. In a recent summary, Kampe-

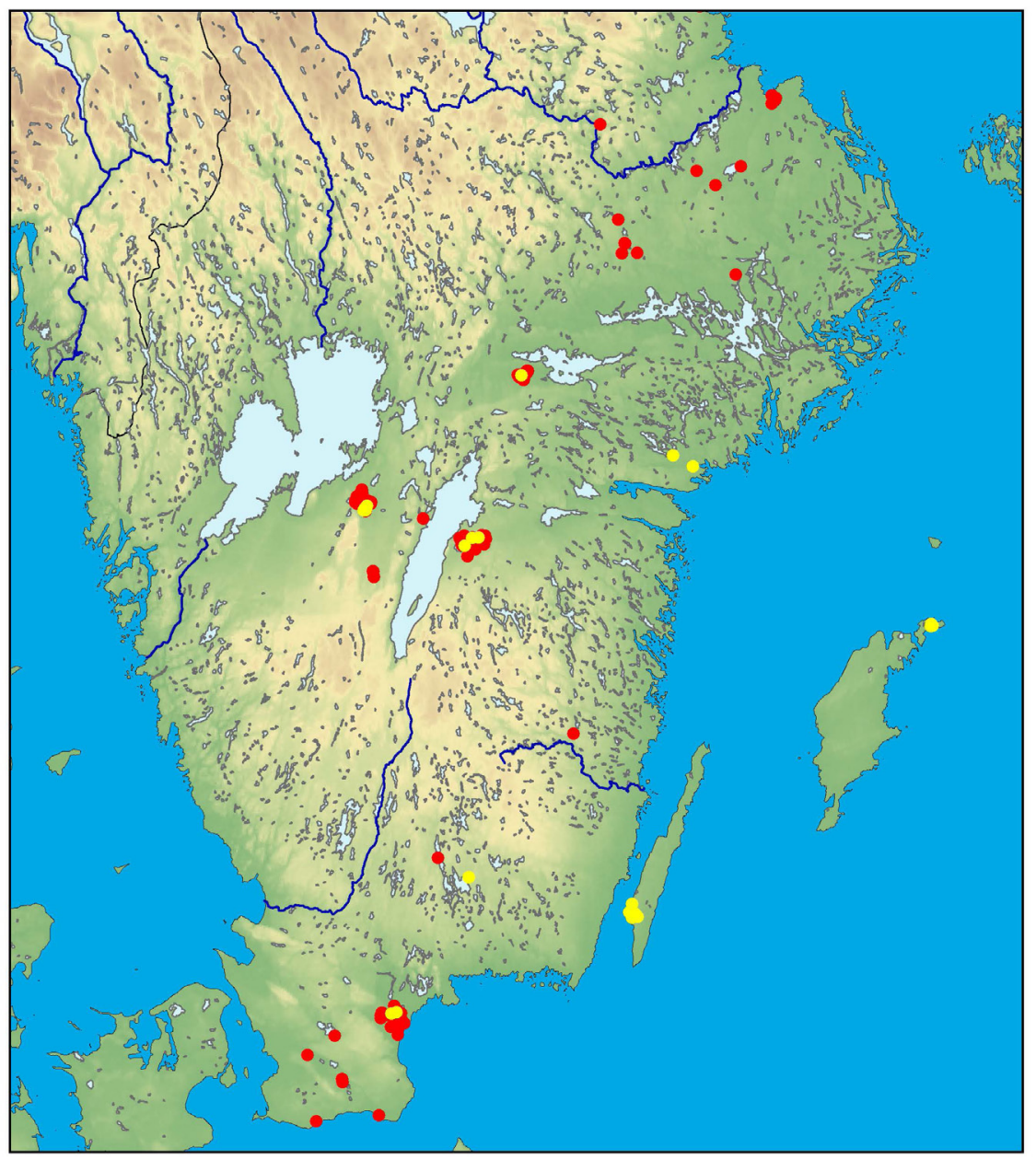

Figure 2. Observations of neck-banded Tundra Bean Geese in central and southern Sweden. Red dots: birds neck-banded in Scandinavia (Norway and Sweden) since 2009, yellow dots: birds neck-banded outside Scandinavia (Russia, Germany, The Netherlands) since 2006. Source: www.geese.org. 
Table 3. Sightings in southern and central Sweden of Tundra Bean Geese neck-banded in and outside Scandinavia. Source: www.geese.org. Birds neck-banded outside Scandinavia were marked in Russia, Germany or The Netherlands. Many birds were observed at multiple sites and/or in multiple years, but the number of individuals for a site (e.g. 59 for Hammarsjön) refers to the total number of unique individuals seen at this site. The sites Ystad, Vombsjön and Ringsjön are in southern Scania.

\begin{tabular}{|c|c|c|}
\hline $\mathrm{N}$ & $\begin{array}{c}\text { Neck-banded } \\
\text { in Scandinavia } \\
\mathrm{N} \text { individuals ( } \mathrm{N} \text { sightings) }\end{array}$ & $\begin{array}{c}\text { Neck-banded } \\
\text { outside Scandinavia } \\
\mathrm{N} \text { individuals (N sightings) }\end{array}$ \\
\hline Östen & $38(102)$ & $3(6)$ \\
\hline Tåkern & $40(160)$ & $3(3)$ \\
\hline Kvismaren & $11 \quad(33)$ & 1 (1) \\
\hline Hammarsjön & $59(257)$ & $2(3)$ \\
\hline Tidaholm & 4 (13) & \\
\hline Ledskär & 4 (11) & \\
\hline Skatelöv & $1 \quad(1)$ & \\
\hline Målilla & $1 \quad(1)$ & \\
\hline Ystad & $1 \quad(1)$ & \\
\hline Vombsjön & 3 (4) & \\
\hline Ringsjön & $2 \quad(2)$ & \\
\hline Grytåsen, Mölltorp & $1 \quad(1)$ & \\
\hline Hjälstaviken & $1 \quad(1)$ & \\
\hline Flinesjön, Hedemora & 1 (1) & \\
\hline Fläcksjön, Salbohed & $5 \quad(8)$ & \\
\hline Tämnaren & 2 (2) & \\
\hline Hällsmyran, E. Tärnsjö & $2 \quad(2)$ & \\
\hline Lidhemssjön, Växjö & & 1 (1) \\
\hline Mörbylånga, Öland & & $2(9)$ \\
\hline Gotland, northern part & & $2(14)$ \\
\hline Stigtomta & & $3(9)$ \\
\hline
\end{tabular}

Persson (2011) reported that he generally found small proportions $(<10 \%)$ of rossicus birds during his 1997-2011 Bean Goose counts in the southern parts of Scania, and argued that these proportions were likely to be representative for the rest of Sweden in midwinter. For autumn counts he concluded that pre-2011 conditions were impossible to verify, but indicated that our findings correlated with a substantial increase in Tundra Bean Geese numbers in Sweden during the past 5-10 years, for which he claimed, but did not report, the existence of strong indications.

The assumption that the Tundra Bean Goose data from southern Scania are representative for the rest of Sweden is contradicted by the fact (a) that only a small proportion $(<3 \%)$ of the Tundra Bean Geese in our counts were observed here, and (b) that only $1 \%$ of the neck-band sightings were reported from southern Scania, despite particularly intensive neck-band reading in this region (Figure 2, Table 3, Nilsson 2011). Instead, Tundra Bean Geese seem to be concentrated at specific sites (Figure 1) where they have not been separated from Taiga Bean Geese during previous goose counts. After a recent Bean Goose identification event at Tåkern (20 Oct. 2012), several of the experienced goose counters acknowledged the presence of substantial numbers of Tundra Bean Geese which they had previously overlooked (e.g. Peter Berglin, pers. comm.).

Thanks to the Tundra Bean Geese neck-banded in northern Norway, northern Sweden and outside Scandinavia, good numbers of neck-bands are currently present among staging and wintering Bean Geese. The pattern of Tundra Bean Goose neck-band sightings (www.geese.org, Figure 2) strongly supports the classification of Bean Geese in our counts. This pattern also indicates that the Tundra Bean Geese in Sweden are of different origin, with some areas holding only Scandinavian birds and others only eastern ones (Figure 2).

Our conclusion is that, since 2009, autumn numbers of Tundra Bean Geese in Sweden commonly ranged between 5000 and 10000 individuals, and given a likely but unknown turn-over rate, the total numbers visiting Sweden may be substantial higher. Also, during mild winters, a large proportion of these Tundra Bean Geese stay in Sweden, mainly in the Hammarsjön area. How conditions were before 2009 cannot be known for sure, but, in contrast to Kampe-Persson (2011), we argue that there is no strong evidence for a major increase over the last decades.

Based on this conclusion, the population estimate 
of Taiga Bean Geese has to be adjusted downward. Taking the Swedish October count data as a standard, the Swedish part of the Taiga Bean Goose population should be reduced by approximately 15\% (7500 out of 50000). This underlines the severity of the situation the Taiga Bean Goose population is in, and calls for urgent conservation and management measures.

Acknowledgements. We thank Leif Nilsson, Paul Shimmings and an anonymous referee for valuable comments on earlier versions of this manuscript. This study was supported by Svensk Våtmarksfond (grants to AdJ).

\section{REFERENCES}

Aarvak, T. \& Øien I.J. 2009. Monitoring of Bean Goose in Finnmark County, Norway - results from 2008. NOF rapport 2-2009.

de Jong, A. 2010a. Sädgåsfångst på Varanger. Vår Fågelvärld 69: 38-39. (In Swedish)

de Jong, A. 2010b. Gör Svalan en sommar? Vår Fågelvärld 69: 46-47. (In Swedish)

Fox, A.D., Ebbinge, B.S., Mitchell, C., Heinicke, T., Aarvak, T., Colhoun, K., Clausen, P., Dereliev, S., Faragó, S., Koffijberg, K, Kruckenberg, H., Loonen, M.J.J.E., Madsen, J, Mooij, J., Musil, P, Nilsson, L., Pihl, S. \& van der Jeugd, H. 2010. Current estimates of goose population sizes in western Europe, a gap analysis and an assessment of trends. Ornis Svecica 20: 115-127.
Heinicke, T. 2010. Tundra Bean Goose Anser fabalis rossicus during spring migration in northern Sweden - rare visitor or regular passage migrant? Ornis Svecica 20: 174-183.

Kampe-Persson, H. 2011. How large proportion of the Bean Geese counted in Sweden was made up of Taiga Bean Geese Anser fabalis fabalis? Ornis Svecica 21: 58-60. (In Swedish with English summary)

Nilsson, L. \& Månsson, J. 2012. International counts of waterbirds, geese and cranes in Sweden. Annual report for 2011/2012. Department of Biology, Lund University \& Viltskadecentrum, Swedish University of Agricultural Sciences. Lund 2012. 56 pp. (In Swedish)

Nilsson, L. \& Persson, H. 1984. Non-breeding distribution, numbers and ecology of Bean Goose Anser fabalis in Sweden. Swedish Wildlife Research, 13: 107-170.

Nilsson, L. 2000. Changes in numbers and distribution of staging and wintering goose populations in Sweden 1977/78 - 1988/89. Ornis Svecica 10: 33-49.

Nilsson, L. 2011. The migration of Finnish Bean Geese Anser fabalis in 1978-2011. Ornis Svecica 21: 157-166.

Nilsson, L., de Jong, A., Heinicke, T. \& Sjöberg, K. 2010. Satellite tracking of Bean Geese Anser fabalis fabalis and $A$. f. rossicus from spring staging areas in northern Sweden to breeding and moulting areas. Ornis Svecica 20: 184-189.

Received 02 December 2012. Accepted 14 June 2013 Guest editor: Paul Shimmings 


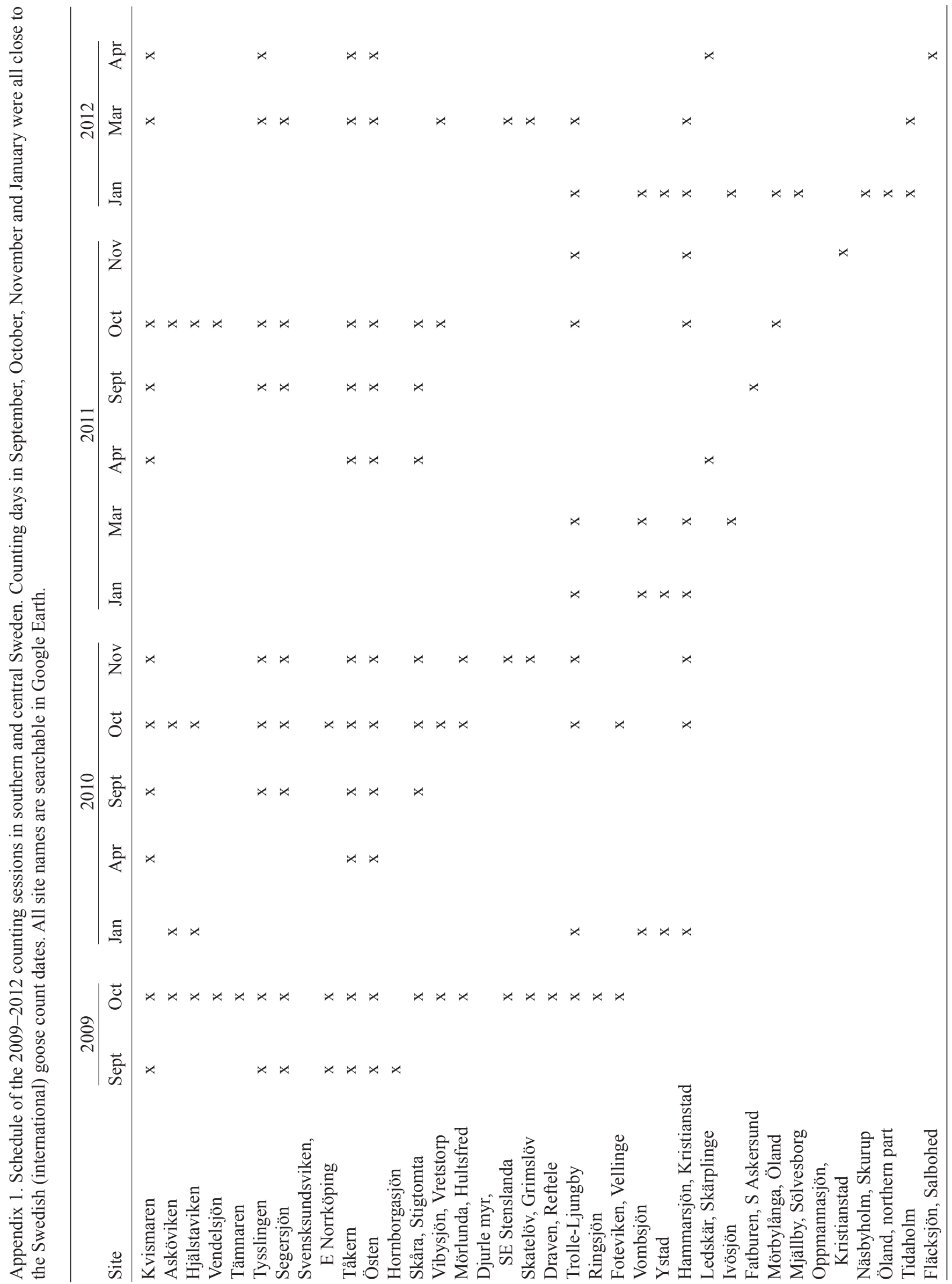

